\title{
Health hazard of using mosquito repellent in Khulna city, Bangladesh
}

\author{
Muniva Islam, Mohammed Ziaul Haider and Sk. Faijan Bin Halim \\ Economics Discipline, Khulna University, Khulna, Bangladesh
}

\begin{abstract}
Purpose - This study examines mosquito-borne diseases and health hazard of using mosquito repellents in Bangladesh. This study also targets to explore the use of different mosquito repellents and associated health hazard between slum and residential people.

Design/methodology/approach - This study has applied a stratified systematic sampling technique taking 120 adult individuals from residential and slum areas covering users and non-users of mosquito repellents of Khulna city, Bangladesh. A structured questionnaire has been used to collect data from respondents.

Findings - Econometric techniques are exercised to examine the occurrence, severity and duration of different respiratory diseases. Results exhibit that poor and less-educated slum people are more prone to face respiratory diseases compared to residential people. The health cost of slum and residential people is estimated US\$ 134 and US $\$ 9$, respectively.

Practical implications - Relevant stakeholders under public health programs should spread awareness among people regarding the negative health effect of using mosquito repellent, encourage them to limit the use of harmful repellent and instead use herbal product (neem coil), avoid using repellent in living room rather use outside of room and close window and use proper bed net at night.

Originality/value - This study underpins arranging public health programs and taking averting actions as an impetus to raise consciousness toward the negative health effect of using mosquito repellents.
\end{abstract}

Keywords Mosquito prevalence, Mosquito born-disease, Mosquito repellent, Respiratory disease, Health cost, Averting action

Paper type Research paper

\section{Introduction}

The word mosquito means "biting fly" (Nkya et al, 2013). Norris (2004) states that mosquito is a small flying insect that bites the skin of people and animals and sucks their blood. Mosquitoes transmit several infectious diseases such as malaria, filarial, yellow fever, dengue fever and West Nile virus that can eventually be deadly to humans (Sharma, 2001). In 2016, an estimated 216 million cases of malaria were found worldwide, with an estimated 4,45,000 deaths. In addition, about 100 million people are affected with dengue fever each year in Africa and Southeast Asia, and supposedly 1 billion people worldwide will be at risk of exposure of dengue in next 50 years (WHO, 2018). Bangladesh, with its high temperature and humidity mainly caused by rapid urbanization and seasonal irregular rain, becomes the most vulnerable to dengue outbreak with acute symptoms

(C) Muniva Islam, Mohammed Ziaul Haider and Sk. Faijan Bin Halim. Published in Journal of Economics and Development. Published by Emerald Publishing Limited. This article is published under the Creative Commons Attribution (CC BY 4.0) licence. Anyone may reproduce, distribute, translate and create derivative works of this article (for both commercial and non-commercial purposes), subject to full attribution to the original publication and authors. The full terms of this licence may be seen at http:// creativecommons.org/licences/by/4.0/legalcode

Ethical declaration: This is a self-funding and original research work. It particularly examines the occurrence, severity and duration of different respiratory diseases along with calculated health cost due to the use of mosquito repellent without deploying any chemical and medicinal experiment on human body. Therefore, research participants are not exposed to any harm in any ways. In addition, no sensitive questions are asked, and their privacy is not disclosed in any form throughout the study.

Conflict of interest: None to declare.
Health hazard of using mosquito repellent

(1)


JED

24,1

66

of fever, muscle aches, headache and rash. Such outbreak of diseases imposes social and economic burden along with impeding economic development through several channels including quality of life, absenteeism, unable to work, loss of labor productivity, premature mortality, loss of savings and medical costs, which all result in more economic burden, that is, cost directly or indirectly associated with diagnosis, treatment and prevention of disease (Castro et al., 2017).

Evidence from some countries find that individual lose their workdays due to different mosquito-borne diseases. For a sick adult in Ghana, average time loss per episode of illness ranges from 1 to 5 days, 18 days in Ethiopia, 2.7 days in Malawi and 6-11 days in Sudan (Chima et al., 2003). This might bear significant rise in treatment cost (i.e. transportation, medication, inpatient and outpatient visit and hospitalization cost), hence in loss in income (Shretta et al.,2016; Hennessee et al., 2017; Khan et al., 2019). A study conducted in Pakistan finds that households spend wide range of money as averting and treatment expenditure to combat burden of mosquito-borne diseases for which they have to bear US\$ 5.10 and US $\$ 4.84$, respectively (Khan et al.,2019). Another study finds that average health cost per episode of mosquito-borne disease is US\$17.48 in Malawi, US\$17.20 in Sudan and US\$24.89 for low-income households in Africa (Chima et al., 2003; Hennessee et al., 2017). Improvement of treatment services merely has little impact on cutting down the expenditure; therefore, preventive strategies like use of cost-effective repellent may justify the potential significance in health outcome.

A greater majority of urban and rural dwellers have been using mosquito repellents since a long period of time, especially in developing countries, because of their economical price and accessibility to the poor people (Hogarh et al., 2016; Naz et al., 2019). Most commonly used residential repellents include sprays, mats and vaporizers, whereas coils and bed nets are highly popular among low-income slum dwellers (Naz et al., 2019; Khan et al., 2019). Repellents cannot fully control mosquito bites but make human unattractive to mosquito (Sah et al., 2010). The effect of repellent may last for 6-8 h, whereas liquid mosquito incense normally lasts for 60 days (Wang et al., 2018). People use these repellents in their day-to-day life without knowing the composition of the product and safety measures (Mehta et al., 2010). It is evident that fine particulate matter released from a single mosquito coil is equal to 75-137 cigarettes (Gul et al., 2013). Continuous or prolonged use of different repellents (at least 8-10 h/day) causes acute respiratory infection like cold, asthma and pneumonia (Wadi et al., 2019). Different mosquito-control strategies have been proven successful as primary prevention strategies for preventing mosquito-borne diseases. Likewise, the use of herbal repellents made from essential oils such as neem oil, horticultural oils, rushed lavender flowers, soybean oil, thyme oil, Greek catnip oil and lemon eucalyptus oil is comparatively safer (Aldila and Seno, 2019). In addition, mosquito cream made from neem oil is considered as an effective repellent (Trivedi et al., 2018).

Several studies have been conducted regarding mosquito-borne diseases and health hazard of using mosquito repellents (Kamble et al., 2012; Gul et al., 2013; Hogarh et al., 2016; Wang et al., 2018; Moore et al., 2018; Naz et al., 2019; Aldila and Seno, 2019). However, a study from Bangladesh's perspective is scarce in the literature. So, to fill the gap and make clear conception on the causes and consequences of health hazard in using mosquito repellents, this study focuses on finding out answers of three research questions.

$R Q 1$. What is the frequency and degree of severity of health hazard for using mosquito repellents?

$R Q 2$. What are the health risks associated with using mosquito repellents?

RQ3. What is the cost of using mosquito repellents?

\section{Sample selection and data collection}

This is a cross-sectional study conducted on two slum and two residential areas of Khulna city where 120 adult respondents are selected following a stratified systematic sampling method. 
Area (slum and residential) is the strata of this study. Respondents are selected through systematic sampling method, while randomness is applied in selecting ward and road.

From the 31 wards in Khulna city, at first, 4 wards are chosen randomly, namely Rupsha (ward no. 22) and Rail Station area (ward no. 21) as two slum areas, and Nirala (ward no. 24) and Sonadanga (ward no. 28) as two residential areas. From 25 roads in Nirala and Sonadanga residential areas, road nos. 8, 11, 14, 17, 20, 23 are chosen randomly to collect information from user and non-user groups of mosquito repellent residing in the first, fifth, tenth, fifteenth and twentieth number of houses. Nearly 10,000 people are currently living in 12 small roads in Rupsha. Accordingly, road nos. 2, 4, 6, 8, 10, 12 are selected randomly to collect information from respondents. Nearly 12,000 people are currently living in Rail Station area. From 700 houses in the Rail Station area, respondents are systematically chosen. Therefore, a total of 120 samples are taken for this study during the study period of January-June 2016 (Table 1).

A structured questionnaire is used to collect data from 120 samples. The survey is administered privately to participants during the daytime when they are available in their home. It takes approximately $30 \mathrm{~min}$ to fill out the questionnaire. The questionnaire covered information regarding respondent's socioeconomic characteristics, usage of repellent, exposure to repellent use, health hazard of using repellents, awareness of using repellents, averting and treatment cost borne by respondents and other related issues coherent with the study objective.

\section{Materials and methods}

Attempts at assessing the use of mosquito repellents and associated health hazards using different econometric techniques have been found to be significant approaches in estimating the economic burden of diseases. However, relatively little is known about the determinants of using mosquito repellents, facing diseases and the costs associated with it, especially in the context of a developing country like Bangladesh. Therefore, a rigorous investigation concentrating on analyzing the use of repellents and magnitude of economic burden would help to identify intervention strategies to reduce such burden. This study is such an endeavor. In doing so, wide varieties of models have been used in this paper following the literature to estimate the frequency, severity, prevalence and associated health risk of using mosquito repellents in the slum and residential areas. This study also calculates the difference in the cost of dealing with illness between slum and residential people due to use of mosquito repellents. Associations among sociodemographic variables and other predictors relevant to the study are explored using tabulation, followed by hypothesis and multivariate regression analyses to adjust for cofounders (Manica et al., 2017; Wu et al., 2017; Moore et al., 2018; Khan et al., 2019).

This study has deployed three logistic regressions to find out the factors affecting indoor congestion, probability of facing respiratory diseases and factors affecting taking averting actions (equation 1 ).

\begin{tabular}{llclccr}
\hline $\begin{array}{l}\text { Serial } \\
\text { no }\end{array}$ & $\begin{array}{l}\text { Name of the } \\
\text { city }\end{array}$ & $\begin{array}{c}\text { Ward } \\
\text { number }\end{array}$ & $\begin{array}{l}\text { Name of the } \\
\text { place }\end{array}$ & $\begin{array}{c}\text { User of } \\
\text { repellent }\end{array}$ & $\begin{array}{c}\text { Non-user of } \\
\text { repellent }\end{array}$ & Total \\
\hline 1 & Khulna & 21 & Rail Station & 20 & 10 & 30 \\
2 & & 22 & Rupsha & 10 & 20 & 30 \\
3 & & 24 & Nirala & 17 & 13 & 30 \\
4 & 28 & Sonadanga & 17 & 13 & 30 \\
& & Total & & & 120
\end{tabular}

Health hazard of using mosquito repellent 


$$
\operatorname{Logit}\left(P_{i}\right)=\log \left(\frac{P_{i}}{1-P_{i}}\right)=\beta_{0}+\sum \beta_{i} X_{i}+u_{i}
$$

where $\log \left(\frac{P i}{1-P_{i}}\right)$ is the odd ratio, $P_{i}$ is the probability of happening the abovementioned three issues, $X_{i}$ stands for explanatory variables and $\beta_{i}$ is the parameter to be estimated.

Two negative binomial regression models (equation 2 ) are used to determine the factors influencing ill days and income loss, where there are several zero observations. Here, negative binomial model is best suited as it accounts for the preponderance of zeros and the discrete nature of the dependent variable.

$$
g=\beta_{0}+\beta_{1} X_{1}+\beta_{2} X_{2}+\ldots+\beta_{i} X_{i}=x_{i}^{T} \beta
$$

where $X_{i}$ represents explanatory variables.

A tobit regression model (equation 3 ) is used to identify the factors influencing treatment cost. Below, the likelihood function for tobit is expressed. This is a tobit that is censored from below at $y_{L}$ when the latent variable $y_{i}^{*} \leq y_{L}$.

$$
y= \begin{cases}1 & \text { if } y_{i}^{*}>y_{L} \\ 0 & \text { if } y_{i}^{*} \leq y_{L}\end{cases}
$$

where $y_{i}^{*}$ is a latent variable.

$$
y_{i}^{*}=X_{1}+u_{i}, u_{i} \sim N\left(0, \sigma^{2}\right)
$$

Cost of illness is calculated by following the paper of Atreya (2007) with the following: equation (4) (for user group), equation (5) (for non-user group) and equation (6) (for net cost of illness).

$$
\begin{gathered}
C_{u}=P_{u} * \mathrm{COI}_{u}+P_{a}^{*} \mathrm{AC} \\
C_{c}=P_{c} * \mathrm{COI}_{c}
\end{gathered}
$$

here,

$C_{u}=$ Average cost for repellent user

$C_{c}=$ Average cost for repellent non-user

$P_{u}=$ Probability of sickness of repellents user

$P_{c}=$ Probability of sickness of repellents Non-user

$\mathrm{COI}_{u}=$ Average cost of treatment for user

$\mathrm{COI}_{c}=$ Average cost of treatment for non-user

$\mathrm{AC}=$ Cost of Aaverting actions for user

Here,

$$
\mathrm{HC}=C_{u}-C_{c}
$$

where, $\mathrm{HC}=$ health cost

Thus, for calculating actual health cost, costs of non-users are subtracted from that of users. 


\section{Research variables}

Operational definition of some relevant variables used in this study is described as follows:

Indoor congestion: Congestion occurs in indoor environment (in a place or room) when it is extremely crowed and blocked with smog, odor, toxic vapors from home pesticides such as mosquito repellent, perfume and tobacco smoke, and there is insufficient outdoor air intake (Atreya, 2007; Kyaw Myint, 2016).

Ill days: Days for which an employee is unpaid while absent due to illness. Hazardous effects of using mosquito repellent on health often make people fall sick because of which they cannot go to their work places, eventually resulting in loss of income (Hennessee et al., 2017; Khan et al., 2019).

Averting action: Averting behavior refers to action taken to defend against environmental or other hazards, whether by reducing exposure to hazards or by mitigating adverse effects of exposure. Since use of repellent generates health hazard in the study areas, taking different averting actions like use of bed net, window screening, electric racket as well as neem product may be treated as avertive actions which can reduce the exposure of different health hazards (Ipa et al., 2020).

Treatment cost: Treatment costs are referred to those expenses incurred with the aim of treating or eliminating diseases. They include medication cost, doctor's fee, diagnostic test fee and transportation cost to visit medical facilities (Chima et al., 2003; Khan et al., 2019).

Cost of illness: Cost of illness technique has been used to determine the probability (both user and non-users, irrespective of slum and residential areas) of being sick due to repellent use and exposure. The predicted probability of outcome (i.e. the probability of observing repellent-related acute symptoms) is estimated for users and non-users. Averting action model has been used to determine probability of an individual adopting averting action while using repellent. In addition, this study calculates average cost of treatment and averting action for an individual in the sample. It is assumed that the cost of averting action for a nonuser is zero. Authors use these predicted probabilities and relevant expenses to obtain the cost of illness due to repellent use (Atreya, 2007; Khan et al., 2019).

\section{Results}

\subsection{Result of research question 1}

Table 2 depicts that about $84 \%$ respondents in slum area are using coil compared to only $2 \%$ in residential area. Moreover, among the respondents in residential area, $38 \%$ use spray, $27 \%$ use liquid vaporizer and $6 \%$ use DEET; in contrast, the corresponding figures for slum area are 13,9 and $2 \%$, respectively. Average expenditure on repellent per month in slum and residential areas is US\$ 3 and US\$ 4, respectively, with US\$ 0.35 mean difference. People in both slum and residential areas face different respiratory diseases irrespective of whether

\begin{tabular}{lcccr}
\hline & & & \multicolumn{2}{c}{ Residence } \\
Repellent category & Frequency & Percentage & Frequency & Percentage \\
\hline Coil & 26 & 84 & 10 & 29 \\
Spray & 4 & 13 & 13 & 38 \\
Liquid vaporizer & 1 & 3 & 9 & 27 \\
DEET & 0 & 0 & 2 & 6 \\
Other (Kazi, Egal) & 0 & 0 & 0 & 0 \\
Total & 30 & 100 & 34 & 100
\end{tabular}

Note(s): Average Repellent Expenditure (BDT per month): Slum = BDT 286; Residence = BDT 316 Mean Difference Repellent Expenditure (BDT per month) = BDT 30

Health hazard of using mosquito repellent

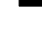


they are repellent user or non-user. From Table 3 , it is clear that people sometimes face eye irritation, nose and throat infection, cough, weakness and headache, while others claim that they frequently face heart disease, asthma, skin allergy and respiratory allergy. Similar finding is observed in other studies (Shi-Chen et al.,2008; Hogarh et al, 2016). This study finds that severity of diseases due to use of repellent is higher in slum area $(63 \%, n=30)$ compared to residential area $(56 \%, n=34)$.

Severity of diseases due to use of mosquito repellent may not be evident at the initial stage, but long-time inhalation of smoke and odor create dangerous health effect to people.

\begin{tabular}{|c|c|c|c|c|c|}
\hline \multirow[b]{2}{*}{ Types of diseases } & \multirow[b]{2}{*}{$\begin{array}{l}\text { Facing } \\
\text { diseases }\end{array}$} & \multicolumn{2}{|c|}{ Slum } & \multicolumn{2}{|c|}{ Residence } \\
\hline & & $\begin{array}{c}\text { Repellent user } \\
(\%)\end{array}$ & $\begin{array}{c}\text { Repellent } \\
\text { non-user (\%) }\end{array}$ & $\begin{array}{l}\text { Repellent user } \\
(\%)\end{array}$ & $\begin{array}{c}\text { Repellent } \\
\text { non-user (\%) }\end{array}$ \\
\hline \multirow[t]{6}{*}{ Eye irritation } & Never & 53 & 77 & 50 & 84 \\
\hline & Very rare & 0 & 0 & 6 & 0 \\
\hline & Sometimes & 30 & 6 & 20 & 4 \\
\hline & Frequently & 7 & 17 & 15 & 4 \\
\hline & $\begin{array}{l}\text { Very } \\
\text { frequently }\end{array}$ & 10 & 0 & 9 & 8 \\
\hline & Total & 100 & 100 & 100 & 100 \\
\hline \multirow{6}{*}{$\begin{array}{l}\text { Nose and throat } \\
\text { infection }\end{array}$} & Never & 83 & 90 & 85 & 88 \\
\hline & Very rare & 0 & 7 & 0 & 8 \\
\hline & Sometimes & 10 & 0 & 6 & 4 \\
\hline & Frequently & 4 & 3 & 6 & 0 \\
\hline & $\begin{array}{l}\text { Very } \\
\text { frequently }\end{array}$ & 3 & 0 & 3 & 0 \\
\hline & Total & 100 & 100 & 100 & 100 \\
\hline \multirow[t]{6}{*}{ Cough } & Never & 53 & 60 & 64 & 73 \\
\hline & Very rare & 27 & 3 & 0 & 0 \\
\hline & Sometimes & 20 & 30 & 15 & 19 \\
\hline & Frequently & 0 & 7 & 15 & 8 \\
\hline & $\begin{array}{l}\text { Very } \\
\text { frequently }\end{array}$ & 0 & 0 & 6 & 0 \\
\hline & Total & 100 & 100 & 100 & 100 \\
\hline \multirow{6}{*}{ Heart diseases } & Never & 77 & 67 & 94 & 84 \\
\hline & Very rare & 3 & 0 & 0 & 4 \\
\hline & Sometimes & 10 & 23 & 3 & 8 \\
\hline & Frequently & 3 & 10 & 3 & 4 \\
\hline & $\begin{array}{l}\text { Very } \\
\text { frequently }\end{array}$ & 7 & 0 & 0 & 0 \\
\hline & Total & 100 & 100 & 100 & 100 \\
\hline \multirow[t]{6}{*}{ Asthma } & Never & 83 & 67 & 70 & 81 \\
\hline & Very rare & 0 & 10 & 0 & 0 \\
\hline & Sometimes & 3 & 6 & 9 & 11 \\
\hline & Frequently & 14 & 10 & 15 & 8 \\
\hline & $\begin{array}{l}\text { Very } \\
\text { frequently }\end{array}$ & 0 & 7 & 6 & 0 \\
\hline & Total & 100 & 100 & 100 & 100 \\
\hline & Never & 54 & 56 & 71 & 69 \\
\hline \multirow{5}{*}{ allergy } & Very rare & 0 & 0 & 0 & 4 \\
\hline & Sometimes & 30 & 27 & 6 & 19 \\
\hline & Frequently & 13 & 17 & 20 & 4 \\
\hline & $\begin{array}{l}\text { Very } \\
\text { freguently }\end{array}$ & 3 & 0 & 3 & 4 \\
\hline & Total & 100 & 100 & 100 & 100 \\
\hline
\end{tabular}

Table 3.

Severity of diseases among user and nonuser of repellent 
Hypothesis testing exhibits that people living in slum areas face more number of sick days as compared to residential areas with a mean difference of 12 days. Moreover, sick days in the case of repellent users are also comparatively higher than non-user $(\phi<0.05)$ (Table 4 ) which is consistent (Khan et al., 2019).

\subsection{Result of research question 2}

Logit regression (equation 1) results exhibit that variable education level, that is, taken as year of schoolin, has expected negative impact $(\phi<0.05)$ on endogenous variable indoor congestion measured as dummy form irrespective whether respondents face any congestion at household level or not. Ventilation facility has significant negative impact $(\phi<0.05)$ on congestion; rooms become congested with smoke if there is lack of ventilation facility in house. Similarly, housing area (in sq. feet) shows negative impact $(\phi<0.01)$ on indoor congestion. The lesser the housing area in size, the greater is the probability of causing congestion. Moreover, presence of smoker within household has positive impact $(\phi<0.01)$ on indoor congestion, as expected. Some other variables, such as repellent use time per day $(<8 \mathrm{~h}=1,>8 \mathrm{~h}=0)(p<0.01)$, use of repellent during sleep (dummy, yes $=1$, no $=0)$ $(\phi<0.05)$, have significant positive impact on indoor congestion (Table 5), which is consistent with the study (Kyaw Myint, 2016).

Another logistic regression (equation 1) has been estimated to find out the predictors affecting probability of facing respiratory diseases measured in dummy form (yes $=1$, no $=0$ ). According to study findings, income shows an expected negative impact $(\phi<0.05)$ on the probability of facing respiratory diseases. If the income of an individual increases, different averting actions (bed net, window screening, electric racket, neem product) are taken for protection from different respiratory diseases. Educated residential people are generally much aware of the negative health effect of using repellent; therefore, if someone lives in a residential area, the probability of facing diseases is $22 \%$ lower $(\phi<0.10)$ compared to one who lives in the slum area. Moreover, awareness of mosquito bites (dummy, yes $=1$, no $=0$ ) shows an expected negative $(\phi<0.10)$ relationship with the probability of facing respiratory diseases. Meanwhile, higher density of mosquito shows expected positive $(p<0.10)$ relationship with the probability of facing respiratory diseases (Table 5). Similar findings have also been observed in other studies (Hogarh et al., 2016; Wadi et al., 2019; Khan et al., 2019).

Third logistic regression (equation 1) has been conducted on probability of taking averting actions measured in dummy form (yes $=1$, no $=0$ ), where predictors like gender, age, education, monthly income, area of residence (residence $=1$, slum $=0$ ), density of mosquito (high $=1$, low $=0$ ), use of repellent during sleep and consultation with doctor have found significant association with the dependent variable. Variable gender shows expected positive impact $(\phi<0.10)$, where males in the families are highly concerned about taking

\begin{tabular}{llccccr}
\hline Null hypothesis & Variables & Obs & Mean & Mean diff & Std. Error & $t$-value \\
\hline $\mathrm{H}_{01}$ & Slum sick days & 30 & 49.77 & 12.37 & 8.31 & 0.97 \\
& Residence sick days & 30 & 37.40 & & 8.83 & \\
$\mathrm{H}_{02}$ & User sick days & 56 & 65.96 & $-23.77^{* *}$ & 6.20 & -2.02 \\
& Non-user sick days & 56 & 41.73 & & 9.04 & \\
$\mathrm{H}_{03}$ & Awareness of residence repellent user & 60 & 0.55 & $0.38^{* * *}$ & 0.06 & 4.30 \\
& Awareness of slum repellent user & 60 & 0.17 & & 0.05 &
\end{tabular}

Note(s): N.B.: ***p $<0.01, * * p<0.05, * p<0.1$

Obs. $=$ Observation, Diff $=$ Difference, Std. $=$ Standard
Health hazard of using mosquito repellent 


\begin{tabular}{|c|c|c|c|c|c|}
\hline $\begin{array}{l}\text { JED } \\
24,1\end{array}$ & Predictors & Unit & $\begin{array}{c}\text { IC } \\
\mathrm{dy} / \mathrm{dx}\end{array}$ & $\begin{array}{l}\text { FRD } \\
\text { dy/dx }\end{array}$ & $\begin{array}{l}\text { TAA } \\
\text { dy/dx }\end{array}$ \\
\hline \multirow[b]{5}{*}{72} & Gender & Male $=1$, Female $=0$ & - & -0.11 & $0.24^{*}$ \\
\hline & Age & Year & - & 0.00 & 0.00 \\
\hline & Education level & Years of schooling & $-0.04^{* *}$ & 0.00 & $0.04^{* *}$ \\
\hline & Living duration & Year & - & -0.00 & - \\
\hline & Income & BDT per month & -0.00 & $-0.00^{* *}$ & -0.00 \\
\hline \multirow{17}{*}{$\begin{array}{l}\text { Table } 5 . \\
\text { Logit regression on } \\
\text { indoor congestion, }\end{array}$} & Household size & $\begin{array}{l}\text { Number } \\
\text { Residence }=1 \mathrm{Sl}\end{array}$ & 0.04 & $-022^{*}$ & $-7^{* * *}$ \\
\hline & $\begin{array}{l}\text { Area of residence } \\
\text { Surrounding living place }\end{array}$ & $\begin{array}{l}\text { Residence }=1 \text {, Slum }=0 \\
\text { Hygienic }=1 \text {, Unhygienic }=0\end{array}$ & $\begin{array}{c}0.31 \\
-\end{array}$ & $\begin{array}{l}-0.22 \\
-0.15\end{array}$ & $\begin{array}{l}0.47 \\
0.09\end{array}$ \\
\hline & Awareness of mosquito bite & Yes $=1$, No $=0$ & - & $-0.20^{*}$ & $\begin{array}{c}0.09 \\
-\end{array}$ \\
\hline & Density of mosquitoes & High $=1$, Low $=0$ & - & $0.18^{*}$ & -0.02 \\
\hline & Housing area & Sq. Feet & $-0.27^{* * * *}$ & - & - \\
\hline & No. of people sleeping in a room & Number & 0.04 & - & - \\
\hline & Ventilation facility & Yes $=1$, No $=0$ & $-0.08^{* *}$ & - & - \\
\hline & Take healthy food & $\mathrm{Yes}=1, \mathrm{No}=0$ & & 0.18 & - \\
\hline & Use repellent during sleep & Yes $=1$, No $=0$ & $0.12^{* * *}$ & -0.16 & $0.65^{* * * *}$ \\
\hline & Using time of repellent & $<8 \mathrm{~h} /$ day $=1,>8 \mathrm{~h} /$ day $=0$ & $0.21^{* * * *}$ & - & - \\
\hline & Smoking status & Yes $=1$, No $=0$ & 0.89 & - & - \\
\hline & Hygiene awareness & Yes $=1$, No $=0$ & - & - & -0.07 \\
\hline & Taking averting action & Yes $=1, \mathrm{No}_{0}=0$ & -0.23 & 0.16 & - \\
\hline & Consult with doctor & Yes $=1$, No $=0$ & 0.18 & 0.10 & 0.02 \\
\hline & No. of observation & & 120 & 120 & 120 \\
\hline & Log likelihood & & -16.93 & -65.62 & -53.42 \\
\hline & Pseudo $R^{2}$ & & 0.60 & 0.11 & 0.35 \\
\hline
\end{tabular}
diseases and taking $\quad$ Note(s): N.B.: $* * * p<0.01, * * p<0.05,{ }^{*} p<0.1$; IC $=$ Indoor Congestion; FRD $=$ Facing Respiratory Diseases; averting action

averting action compared to female member. Educated people are highly conscious of negative health effect in using mosquito repellent, so they have higher probability $(p<0.05)$ of taking averting actions. The study also finds that if someone lives in a residence area, the probability of taking averting action is $47 \%$ higher $(\phi<0.05)$ compared to one who lives in the slum area. Using repellent during sleep may create problem in inhaling, or exposure to such smoke may create different respiratory diseases. So, if someone uses repellent during sleep, then the probability of taking averting action is $65 \%(p<0.01)$ higher compared to others who do not use repellent during sleep (Table 5). The above findings are coherent with the study (Khan et al., 2019).

Negative binomial regression model (equation 2) has been used taking ill days of an individual as dependent variable. It is found that predictors such as age, education level, income, surrounding living place (hygienic $=1$, unhygienic $=0$ ) and taking averting action have negative impact, while area of residence, and use of repellent during sleep have positive impact on ill days. This finding is quite consistent with the study (Khan et al., 2019). Ill days of the respondent are expected to decrease by 0.04 days $(p<0.10)$ with 1 year increase of age. Variable education level has expected negative impact $(\phi<0.10)$ on ill days, as educated people take better steps while falling sick; therefore, the chance of getting sick decreases. As respondents use repellent during sleep, the exposure to smoke may cause different respiratory diseases and consequently the individual may face ill days $(\phi<0.05)$. Surprisingly, consultation with doctor shows positive impact on the ill days $(\phi<0.01)$, because respondents do not always follow guidelines as prescribed by doctors which is consistent with the study (Tinuade et al., 2010) (Table 6).

Another negative binomial regression (equation 2) has been estimated by taking income loss of an individual per episode of illness as a dependent variable. Factors such as education 
level, density of mosquitoes and taking averting action have significant impact on income loss. People who are educated $(p<0.10)$ become more cautious of taking preventive actions to avoid respiratory diseases, so they do not have to bear any income loss. Moreover, in areas with high density of mosquitoes, people are more aware of taking preventive actions, and consequently income loss decelerates $(\phi<0.05)$. Moreover, income loss is expected to rise $(p<0.05)$ if someone takes averting actions with compared to those who do not take any (Table 6). These findings are consistent with other studies (Hennessee et al., 2017; Khan et al., 2019).

\subsection{Result of research question 3}

Table 7 presents tobit regression (equation 3) result on treatment cost (summation of doctor's fee, medicine cost, hospital expenses and transport cost of visiting a doctor) as dependent variable. Result portrays that if age increases by 1 year, total treatment cost increases by US\$ $4(p<0.05)$. It is found that educated people are highly conscious of their health and spend on an average US $\$ 9(\phi<0.10)$ whenever they fall sick. If household size increases by one member, then treatment cost decreases by US $\$ 9(p<0.01)$. It is seen that as number of members in the family increase, their experience may help each other to take better preventive strategies to reduce diseases, and hence the treatment cost. It is certain that there is a less probability of illness if someone lives in a hygienic hygiene area; hence, treatment cost lowers by US $\$ 157(p<0.05)$ compared to those who live in an unhygienic area represented as shanty living environment, poor sanitation facility and presence of high density of mosquitoes. Dealing with mosquito-borne disease shows a statistically significant positive relation $(p<0.05)$ with the treatment cost. Moreover, if the number of sick people in a family increases due to congestion; treatment cost rises by US $\$ 33(p<0.05)$. The study finds

\begin{tabular}{|c|c|c|c|c|c|}
\hline \multirow[b]{2}{*}{ Predictors } & \multirow[b]{2}{*}{ Unit } & \multicolumn{2}{|c|}{ Ill days } & \multicolumn{2}{|c|}{ Income loss } \\
\hline & & $\begin{array}{l}\text { Disp. } \\
\text { Coeff }\end{array}$ & $\begin{array}{l}\text { Std. } \\
\text { Err }\end{array}$ & $\begin{array}{l}\text { Disp. } \\
\text { Coeff }\end{array}$ & $\begin{array}{l}\text { Std. } \\
\text { Err }\end{array}$ \\
\hline Gender & Male $=1$, Female $=0$ & 0.01 & 0.22 & & \\
\hline Age & Year & $-0.04^{*}$ & -0.20 & -0.28 & -5.43 \\
\hline Education level & Year of schooling & $-0.18^{*}$ & -2.11 & $-0.42^{*}$ & -4.29 \\
\hline Income & BDT per month & -0.00 & -0.20 & - & - \\
\hline Area of residence & Residence $=1$, Slum $=0$ & 0.39 & 5.25 & -1.88 & -15.11 \\
\hline Surrounding living place & $\begin{array}{l}\text { Hygienic }=1, \\
\text { Unhygienic }=0\end{array}$ & -0.45 & -1.53 & - & - \\
\hline Density of mosquitoes & $\operatorname{High}=1$ low $=0$ & 1.34 & 0.47 & $-7.29^{* * *}$ & -9.48 \\
\hline Use repellent during sleep & $\mathrm{Yes}=1, \mathrm{No}=0$ & $0.23^{* * *}$ & 2.86 & - & - \\
\hline Ventilation facility & Yes $=1, N_{0}=0$ & - & - & 3.00 & 8.19 \\
\hline Consult with doctor & Yes $=1, N_{0}=0$ & $1.65^{* * * *}$ & 0.24 & -2.43 & -9.42 \\
\hline $\begin{array}{l}\text { Bear money to prevent } \\
\text { expenses }\end{array}$ & & - & - & 2.34 & 5.44 \\
\hline Taking averting action & Yes $=1$, No $=0$ & 0.91 & -1.63 & $4.77^{* * *}$ & 1.07 \\
\hline Taking healthy food & $\mathrm{Yes}=1, \mathrm{No}_{\mathrm{O}}=0$ & - & - & -3.23 & -4.54 \\
\hline $\begin{array}{l}\text { Participation in NGO } \\
\text { program }\end{array}$ & & - & - & -4.29 & -6.09 \\
\hline Constant & & 3. & & 13 & \\
\hline No. of observation & & 12 & & 1 & \\
\hline Log likelihood & & -34 & & -28 & \\
\hline Pseudo $R^{2}$ & & 0. & & 0 & \\
\hline
\end{tabular}

Note(s): N.B.: $* * * p<0.01, * * p<0.05, * p<0.1$; Disp. $=$ Dispersion, Coeff. $=$ Coefficient, Std. $=$ Standard, Err. $=$ Error
Health hazard of using mosquito repellent 


\section{JED 24,1}

\section{4}

Tobit regression on total treatment cost

\begin{tabular}{llrr}
\hline Predictors & Unit & Coefficient & \multicolumn{1}{c}{$\mathrm{dy} / \mathrm{dx}$} \\
\hline Age & Year & $317.68^{* * *}$ & 317.68 \\
Education level & Years of schooling & $724.12^{*}$ & 724.12 \\
Income & BDT per Month & -0.10 & -0.10 \\
Household size & Number & $-4,343.99^{* * *}$ & $-4,343.99$ \\
Area of residence & Residence $=1$, slum $=0$ & $2,753.69$ & $2,753.69$ \\
Surrounding living place & Hygienic $=1$, unhygienic $=0$ & $-13,274.92^{* *}$ & $-13,274.92$ \\
Facing respiratory disease & Yes = 1, No = 0 & $8,262.80^{* *}$ & $8,262.80$ \\
No. of sick people due to congestion & Number & $2,827.51^{* *}$ & $2,827.51$ \\
Taking averting action & Yes $=1$, No $=0$ & $-13,160.97^{* *}$ & $-13,160.97$ \\
Consult with doctor & Yes $=1$, No $=0$ & $22,139.90^{* * *}$ & $22,139.90$ \\
Constant & & $-38,984.16$ & $-38,984.16$
\end{tabular}

Note(s): N.B.: $* * * p<0.01, * * p<0.05, * p<0.1$; Dependent Variable $=$ Total Treatment Cost; Number of Observation: 120; Log Likelihood: -192.33 ; Pseudo $R^{2}=0.14$

that if someone takes averting action, then total treatment cost is reduced by US $\$ 155$ $(p<0.05)$. Consultation with doctor also increases treatment cost by US $\$ 155(\phi<0.01)$. Similar findings are also observed in other studies (Shretta et al., 2016; Khan et al., 2019).

The study finds that different types of averting actions have been taken by the respondents, both in slum and in residential areas, and most of them use bed net along with window screening, electric racket and neem products to control mosquito bites. On an average, slum people spend US $\$ 7(n=30)$ while residential people spend US $\$ 23(n=34)$ on averting actions per month, with mean difference of US\$ 4 (Table 8).

Table 9 demonstrates the estimation of the health cost of slum and residential people (equations 4-6) due to use of mosquito repellent. Result exhibits that the total cost of

\begin{tabular}{lcr}
\hline Averting strategy & Slum & Residence \\
\hline Bed net & 4.65 & 9.77 \\
Window screening & 0.00 & 8.75 \\
Electric racket & 2.50 & 4.00 \\
Neem product & 0.00 & 0.00 \\
Total & 7.15 & 22.52 \\
Note(s): Mean difference of average averting expenditure (US\$ per month) $=$ US $\$ 4$ &
\end{tabular}

Table 8.

Average averting expenditure: US\$ per month

\begin{tabular}{lcc}
\hline Cost of illness determination (US\$) & $\begin{array}{c}\text { Slum (user and } \\
\text { non-user) }\end{array}$ & $\begin{array}{c}\text { Residence (user and } \\
\text { non-user) }\end{array}$ \\
\hline Predicted probability of a user being sick $\left(P_{u}\right)$ & 0.23 & 0.28 \\
Predicted probability of a non-user being sick $\left(P_{c}\right)$ & 0.29 & 0.20 \\
Predicted probability of taking averting actions $\left(P_{a}\right)$ & 0.43 & 0.57 \\
Average costs of treatment for users $\left(\mathrm{COI}_{u}\right)$ & 93.53 & 90.26 \\
Average costs of treatment for non-users $(\mathrm{COI})$ & 27.98 & 98.21 \\
Average costs of averting actions for users $(\mathrm{AC})$ & 1.88 & 6.08 \\
Average costs for repellent users: & 22.32 & 28.74 \\
$C_{u}=P_{u}^{*} \mathrm{COI}_{u}+P_{a}^{*} \mathrm{AC}$ & & 19.64 \\
Average costs for repellent non-users: $C_{c}=P_{c}^{*} \mathrm{COI}_{c}$ & $1,136.55$ & 727.53 \\
Actual health cost, $\mathrm{HC}=C_{u}-C_{c}$ (in BDT) & &
\end{tabular}

Table 9.

Cost of illness determination in slum and residence area (user and non-user)
Average costs for repellent non-users: $C_{c}=P_{c}{ }^{*} \mathrm{COI}_{c}$ Actual health cost, $\mathrm{HC}=C_{u}-C_{c}$ (in BDT)


treatment for the repellent user group is higher than for the non-user group in slum area, which shows contradictory result from the case of users and non-user group in residential area. However, the actual cost of illness for the residential and slum repellent user group in residential and slum areas is US\$ 9 and US\$13, respectively, which is considerably high for the low-income slum dwellers, and this result is consistent with the study (Hennessee et al., 2017).

\section{Discussion}

Mosquito is a common problem in Bangladesh as it is lies in the tropical zone and spreads deadly diseases like dengue, malaria, filaria, yellow fever and West Nile virus. Every year, many people die from these diseases (Yang et al., 2018). To control mosquito, different mosquito repellents are increasingly used by people (Kamble, 2012) living in both residential and slum areas of Khulna city. This study exerts that among different categories of repellents, coil is mostly used in slum areas because of its cheap price and easy portability; however, this observation is consistent with other studies (Lawrence and Croft, 2004; Hogarh et al., 2016). In contrast, other categories like spray, liquid vaporizer and DEET are on high demand, especially in residential areas. Respondents in the study areas use these repellents frequently or sometimes according to their brand preference considering factors such as low price, effectiveness, good quality and no smoke; similar findings also exhibit in another study (Mehta et al., 2010). Respondents in both slum and residential areas spend a large portion of their monthly income for purchasing their preferred repellents. However, through using such repellents, they are affected by different respiratory diseases including eye irritation, nose and throat infection, cough, weakness, heart diseases and asthma, as also observed in the study (Lawrence and Croft, 2004); these repellents are rich in toxic chemicals, and spraying or burning of these repellents releases high amount of toxic particulate matter that mixes with indoor air and ultimately pollutes the air (Nkya et al., 2013). There are bunch of evidences in United States, India and other countries on indoor use of repellent and their harmful effect on human health due to exposure of smoke inside the house (Liu et al., 2003).

Similar findings from other countries are aligned with this study result where age, education, area of residence, income, awareness of mosquito bites and averting actions have strong association with the probability of facing respiratory diseases due to use of mosquito repellent (Sharma, 2001; Hennessee et al., 2017). In residential areas, despite awareness of health risk of mosquito repellents, people are still using it, whereas in slum areas, due to ignorance, very few people are aware of the health risk of using repellents. Moreover, though number of repellent users is high in residential areas, their use and brand choice are comparatively better than people in slum areas; they mostly use repellent at nighttime, and this result is consistent with the study (Nagoor et al., 2017). About 80\% respondents in slum areas use repellent for $5-8 \mathrm{~h}$ per day, while in residential areas, about $56 \%$ respondents use repellent for $<5 \mathrm{~h}$ per day. Similar finding is observed in other studies (Liu et al., 2003; Okine et al., 2004).

Severity of disease is higher in slum areas; therefore, respondents have to bear high treatment cost along with work day loss whenever they face respiratory diseases. This result is consistent with the study (Catsro et al., 2017; Khan et al., 2019). Mainly two types of costs are addressed, which are averting expenses and treatment costs (Khan et al., 2019). The estimated result indicates that total health costs per episode of illness in residence and slum area are US\$ 9 and US\$ 13, respectively, which for the low-income slum dwellers is very high; these results are congruous to other studies (Hennessee et al., 2017; Khan et al., 2019). Since use of repellent generates health cost in the study areas, taking different averting actions like use of bed net, window screening, electric racket as well as neem products can reduce the probability of respiratory diseases. Some related studies also show that using herbal

Health hazard of using mosquito repellent 
JED

24,1

repellents such as mosquito coil and cream consisting of neem oil is considered safe and effective (Rowland et al., 2004; Trivedi et al., 2018).

The findings of the study postulate that the primary way to control mosquito in both slum and residential setting is to use mosquito repellents. However, in a broader sense, the problem can be resolved by public health decision-makers and policy planners taking some integrated approaches (e.g., sound environmental practices, community education, participation of NGOs) to ensure equity, especially at the slum settings (Castro et al., 2017; Kusuma et al., 2019). City Corporation in Khulna though kills larvae and ensures effective mosquito control for short term, it rarely ensures prevention from mosquito-transmitted diseases (Mohiuddin, 2019). Despite several guidelines provided through media campaigns, it is important that the healthcare practitioners share recommendations on safe and effective use of these repellents among general mass. Moreover, achieving equity and sustainability, favor free distribution of mosquito repellent (natural neem product, bed net and mosquito cream) can be carried out in slum areas by private sector retail market along with other free services such as immunization to reach all those in need. In addition, considering the deleterious impact of mosquito repellent over human body, research on effective repellents should be taken under consideration for developing a sustainable method of repellent control (Trivedi et al., 2018).

This study has its sets of limitations due to possibly interviewer bias and small sample size along with area coverage. In addition, although it provides an evidence of using different repellents and the extent of health hazards at the household level, it is based on quantitative survey particularly conducted on recall basis especially to trigger health burden. This static approach sometimes fails to capture the costs that spread beyond the recall basis, inadequate investigation of different repellents exposure on human health and seasonal variations of burdens despite use of different mosquito repellents. Thus, longitudinal approaches with larger sample sizes are recommended as a further research option on this topic.

\section{Conclusion and recommendation}

This study predominantly targets to explore the use of different mosquito repellents and associated health hazard between slum and residential people. Wide varieties of differences come out from study result between these two groups in terms of their socioeconomic characteristics, repellent use, facing diseases, along with economic burden per episode of illness. Result exhibits that mosquito problem is comparatively higher in slum areas due to congested living environment and unhygienic situation because inefficient waste management blocks the drainage system. However, due to wider variation of education and income level, use of mosquito repellents varies according to the demand of brand preference, price level and easy accessibility. It is found that poor slum people mainly use cheaper coil of local brand, whereas residential people use varieties of repellents like spray, liquid vaporizer and DEET. However, this finding is quite consistent with the study (Moore et al., 2018). Study findings postulate that smoke generated from indoor air pollution often poses different respiratory diseases. Such severity is higher in slum areas compared to residential inhabitants because most slum people live in congested environment. People of slum areas suffer more from eye irritation, nose and throat infection, asthma, heart disease and respiratory allergy. In extreme cases, they suffer from loss of income due to loss of workdays. In addition, they have to bear high out-of-pocket cost for consulting doctor and taking treatment. However, to avoid such burden, different averting actions are taken for which expenses are made on purchasing bed net, use of herbal product and electric racket. Slum people on average spend US\$ 7, while residential people spend US\$23 on averting activities per month. On estimating cost of illness, it is found that residential and slum repellent users spend, on average, US\$ 9 and US\$ 13 respectively. This amount is considerably high for the low-income slum dwellers. Therefore, relevant stakeholders under 
public health programs should spread awareness among people regarding the negative health effect of using mosquito repellent, encourage them to limit the use of harmful repellent and instead use herbal product (neem coil), avoid using repellent in living room rather use outside of room and close window and use proper bed net at night. Further research can be managed by engaging several stakeholders to understand the potential health impact on local repellent use. Thus, knowing how people from different strata defend themselves against mosquitoes, and gathering such information using other data, they can improve the method of using such repellents with greater efficacy.

\section{References}

Aldila, D. and Seno, H. (2019), "A population dynamic model of mosquito-borne disease transmission, focusing on mosqutoes' based distribution and mosquito repellent use", Bulletin of Mathematical Biology, Vol. 81 No. 12, pp. 4977-5008.

Atreya, K. (2007), "Pesticide use in Nepal: understanding health costs from short-term exposure", SANDEE working paper, Kathmandu.

Castro, M.C., Wilson, M.E. and Bloom, D.E. (2017), "Disease and economic burdens of dengue", The Lancet Infectious Diseases, Vol. 17 No. 3, pp. 70-78.

Chima, I.R., Goodman, A.C. and Mills, A. (2003), "The economic impact of malaria in Africa: a critical review of the evidence", Health Policy, Vol. 63 No. 1, pp. 17-36.

Gul, S., Ibrahim, S., Wasif, N., Zafar, A. and Syed, R. (2013), "Mosquito repellents: killing mosquito or yourselves", Journal of Scientific and Innovative Research, Vol. 2 No. 6, pp. 1052-1057.

Hennessee, I., Chinkhumba, J., Briggs-Hagen, M., Bauleni, A., Shah, M.P., Chalira, A., Moyo, D., Dodoli, W., Luhanga, M., Sande, J. and Ali, D. (2017), "Household costs among patients hospitalized with malaria: evidence from a national survey in Malawi”, Malaria Journal, Vol. 16 No. 1, p. 395.

Hogarh, J.N., Antwi-Agyei, P. and Obiri-Danso, K. (2016), "Application of mosquito repellent coils and associated self-reported health issues in Ghana", Malaria Journal, Vol. 15 No. 1, p. 61.

Ipa, M., Widawati, M., Laksono, A.D., Kusrini, I. and Dhewantara, P.W. (2020), "Variation of preventive practices and its association with malaria infection in eastern Indonesia: findings from community-based survey", PloS One, Vol. 15 No. 5, p. e0232909.

Kamble, V.S. (2012), "Study of chronic treatment mosquito repellent liquid inhalation on biochemical constitutions of rat", International Journal of Applied Biology and Pharmaceutical Thchnology, Vol. 4 No. 3, pp. 189-192.

Khan, M., Mahmood, H.Z., Noureen, S., Muhmood, K., Husnain, M.I.U. and Hameed Khaliq, I. (2019), "The health burden of malaria and household choices regarding treatment and prevention in Pakistan”, Tropical Biomedicine, Vol. 36 No. 3, pp. 664-676.

Kusuma, Y.S., Burman, D., Kumari, R., Lamkang, A.S. and Babu, B.V. (2019), "Impact of health education based intervention on community's awareness of dengue and its prevention in Dlehi, India”, Global Health Promotion, Vol. 26 No. 1, pp. 50-59.

Kyaw Myint, O. (2016), "Effects of mosquito coil smoke inhalation on human health", Journal of the Myanmar Academy of Arts and Science, Vol. 16 Nos 1-2, pp. 1-14.

Lawrence, C.E. and Croft, A.M. (2004), "Do mosquito coils prevent malaria? A systematic review of trials", Journal of Travel Medicine, Vol. 11 No. 2, pp. 92-96.

Liu, W., Zhang, J., Hashim, J.H., Jalaludin, J., Hashim, Z. and Goldstein, B.D. (2003), "Mosquito coil emissions and health implications", Environmental Health Perspectives, Vol. 111 No. 12, pp. 1454-1460.

Manica, M., Cobre, P., Rosa, R. and Caputo, B. (2017), "Not in my backyard: effectiveness of outdoor residual spraying from hand-held sprayers against the mosquito Aedes albopictus in Rome, Italy", Pest Management Science, Vol. 73 No. 1, pp. 138-145.
Health hazard of using mosquito repellent 
JED

24,1

Mehta, D., Anand, G.A.R.G. and Mehta, N.K. (2010), "Rural buyers' perception about mosquito repellants”, Economia. Seria Management, Vol. 13 No. 1, pp. 43-52.

Mohiuddin, A.K. (2019), "Dengue protection and cure: Bangladesh perspective", European Journal of Sustainable Development Research, Vol. 4 No. 1, p. em0104.

Moore, E.L., Scott, M.A., Rodriguez, S.D., Mitra, S., Vulcan, J., Cordova, J.J., Chung, H.N., de Souza, D.L.L., Gonzales, K.K. and Hansen, L.A. (2018), "An online survey of personal mosquitorepellent strategies", PeerJ, Vol. 6, p. e.5151.

Nagoor, K., Babu, S., Kahn, S., Kalluri, R.J. and John, K. (2017), "Knowledge, attitude and practice on dengue fever and its prevention and control measures in urban slums of South India”, International Journal of Community and Public Health, Vol. 4 No. 8, pp. 3013-3017.

Naz, M., Rehman, N., Ansari, M.N., Kamal, M., Ganaie, M.A., Awaad, A.S. and Alqasoumi, S.I. (2019), "Comparative study of subchronic toxicities of mosquito repellents (coils, mats and liquids) on vital organs in Swiss albino mice”, Saudi Pharmaceutical Journal, Vol. 27 No. 3, pp. 348-353.

Nkya, T.E., Akhouayri, I., Kisinza, W. and David, J.P. (2013), "Impact of environment on mosquito response to pyrethroid insecticides: facts, evidences and prospects", Insect Biochemistry and Molecular Biology, Vol. 43 No. 4, pp. 407-416.

Norris, D.E. (2004), "Mosquito-borne diseases as a consequence of land use change", EcoHealth, Vol. 1 No. 1, pp. 19-24.

Okine, L.K.N., Nayarko, G.E., Armah, B., Awumbila, K., Owusu, S., Set-Soafia, S. and Ofosuhnea, M. (2004), "Adverse effect of mosquito repellent coil smoke on lung, liver and certain drug metabolising enzymes in male wistar albino rat”, Ghana Medical Journal, Vol. 38 No. 3, pp. 89-95.

Rowland, M., Freeman, T., Downey, G., Hadi, A. and Saeed, M. (2004), "DEET mosquito repellent sold through social marketing provides personal protection against malaria in an area of all-night mosquito biting and partial coverage of insecticide-treated nets: a case-control study of effectiveness", Tropical Medicine and International Health, Vol. 9 No. 3, pp. 343-350.

Sah, M.L., Mishra, D., Sah, S.P. and Rana, M. (2010), "Formulation and evaluation of herbal mosquito repellent preparations", Indian Drugs, Vol. 47 No. 4, pp. 45-50.

Sharma, V.P. (2001), "Health hazards of mosquito repellents and safe alternatives", Current Science, Vol. 80 No. 3, pp. 341-343.

Shi-Chen, C., Ruey-Hong, W., Li-Jie, S., Ming-Chih, C. and Huei, L. (2008), "Exposure to mosquito coil smoke may be a risk factor for lung cancer in Taiwan”, Journal of Epidemiology, Vol. 18 No. 1, pp. 19-25.

Shretta, R., Avancena, A.L. and Hatefi, A. (2016), "The economics of malaria control and elimination: a systematic review", Malaria Journal, Vol. 15 No. 1, p. 593.

Tinuade, O., Iyabo, R.A. and Durutoye, O. (2010), "Health-care-seeking behavior for childhood illnesses in resource-poor setting", Journal of Pediatrics and Child Health, Vol. 46 No. 5, pp. 238-242.

Trivedi, A., Rai, P., Kumar, J. and Trivedi, C.A. (2018), "Formulation of low smoke herbal mosquito repellent sticks by using different essential oils", The Pharma Innovation Journal, Vol. 7 No. 4, pp. 173-175.

Wadi, Y., Rantetampang, A.L., Sandjaja, B. and Mallongi, A. (2019), "Factors influencing acute respiratory infection incidence to child under five years in sentani health primary Jayapura district”, International Journal of Science and Healthcare Research, Vol. 4 No. 1, pp. 274-283.

Wang, L., Zheng, X., Stevanovic, S., Xiang, Z., Liu, J., Shi, H., Yu, M. and Zhu, C. (2018), “Characterizing pollutant emissions from mosquito repellents incenses and implications in risk assessment of human health", Chemosphere, Vol. 191, pp. 962-970.

World Health Organization (WHO) (2018), "Dengue and severe dengue", available at: https://www. who.int/news-room/fact-sheets/detail/dengue-and-severe-dengue (accessed 20 August 2017). 
Wu, C., Guo, X., Zhao, J., Lv, Q., Li, H., McNeil, E.B., Chongsuvivatwong, V. and Zhou, H. (2017), "Behaviors related to mosquito-borne diseases among different ethnic minority groups along the China-Laos border areas", International Journal of Environmental Research and Public Health, Vol. 14 No. 10, p. 1227.

Yang, H., Yang, H., Li, Z., Liu, L., Wang, W., He, T., Fan, F., Sun, Y., Liu, J., Li, Y. and Zeng, X. (2018), "Japanese encephalitis virus/yellow fever virus chimera is safe and confers full protection against yellow fever virus in intracerebrally challenged mice", Vaccine, Vol. 36 No. 18, pp. 2450-2455.

Health hazard of using mosquito repellent

Corresponding author

Sk. Faijan Bin Halim can be contacted at: faijan@econ.ku.ac.bd

For instructions on how to order reprints of this article, please visit our website: www.emeraldgrouppublishing.com/licensing/reprints.htm Or contact us for further details: permissions@emeraldinsight.com 